\title{
Pengaruh Pendapatan Asli Daerah (PAD), Dana Alokasi Umum (DAU), dan Penanaman Modal Dalam Negeri (PMDN) terhadap Produk Domestik Regional Bruto (PDRB) Provinsi Jawa Barat 2003-2017
}

Rani Wulantari *, Meidy Haviz

Prodi Ilmu Ekonomi, Fakultas Ekonomi dan Bisnis, Universitas Islam Bandung, Indonesia.

*1raniwlan@gmail.com, meidyhaviz@gmail.com

\begin{abstract}
This study aims to identify and analyze how and how much influence PAD, DAU, and PMDN on West Java Province GRDP 2003-2017. The research method used is quantitative and qualitative methods. The type and source of data used are secondary data obtained from BPS based on time series and cross sections, which is 15 years. The analytical method used is the Ordinary Least Square (OLS) method using the Eviews version 9.0 program. The tests performed are classical assumptions (Multicollinearity, Autocorrelation, Heteroscedasticity, and Normality) and statistical tests are then performed economic analysis. The results showed that PAD and DAU influence and significant effect on GRDP while PMDN has an effect but not significantly on GRDP.
\end{abstract}

Keywords: Original Regional Finance Revenue (PAD), General Allocation Fund (DAU), Domestic Investment (PMDN), Gross Regional Domestic Product (GRDP). Abstrak. Penelitian ini bertujuan untuk mengidentifikasi dan menganalisis bagaimana dan seberapa besar
pengaruh PAD, DAU, dan PMDN terhadap PDRB Provinsi Jawa Barat 2003-2017. Metode penelitian yang
digunakan adalah metode kuantitatif dan kualitatif. Jenis dan sumber data yang digunakan adalah data sekunder
yang di peroleh dari BPS berdasarkan waktu time series dan cross section yaitu selama 15 tahun. Metode
analisis yang digunakan adalah metode Ordinary Least Square (OLS) dengan menggunakan program Eviews
versi 9.0. pengujian yang dilakukan yaitu asumsi klasik (Multikolinear, Autokorelasi, Heteroskedastis, dan
Normalitas) dan uji statistik kemudian dilakukan analisis ekonomi. Hasil penelitian menunjukkan bahwa PAD
dan DAU berpengaruh dan signifikan terhadap PDRB sedangkan PMDN berpengaruh tetapi tidak signifikan
terhadap PDRB

Kata Kunci: Pendapatan Asli Daerah (PAD), Dana Alokasi Umum (DAU), Penanaman Modal Dalam Negeri (PMDN), Produk Domestik Regional Bruto (PDRB). 


\section{A. Pendahuluan}

Menurut Robert Solow pertumbuhan ekonomi adalah rangkaian kegiatan yang salah satunya bersumber dari hasil/output. Hasil/output yang dimaksud oleh Robert Solow adalah Produk Domestik Regional Bruto (PDRB). Badan Pusat Statistik mengartikan PDRB sebagai jumlah nilai tambah yang dihasilkan oleh seluruh unit usaha dalam suatu wilayah, atau merupakan jumlah seluruh nilai barang dan jasa akhir yang dihasilkan oleh seluruh unit ekonomi di suatu wilayah. Untuk menunjukkan laju pertumbuhan ekonomi secara keseluruhan atau setiap lapangan usaha dari tahun ke tahun digunakan nilai PDRB menurut harga konstan (BPS,2017).

Berdasarkan data Badan Pusat Statistik Nasional tahun 2017, berikut adalah provinsi dengan Jumlah PDRB terbesar di Indonesia :

Tabel 1.1 Provinsi dengan Jumlah PDRB Tertinggi di Indonesia Tahun 2017

\begin{tabular}{|c|l|c|}
\hline Peringkat & Provinsi & PDRB (Juta Rupiah) \\
\hline 1 & DKI Jakarta & $1,635,856,000.00$ \\
\hline 2 & Jawa Timur & $1,482,147,600.00$ \\
\hline 3 & Jawa Barat & $1,343,864,432.16$ \\
\hline
\end{tabular}

Sumber : BPS

Dan berikut adalah provinsi dengan jumlah penduduk terbanyak di Indonesia :

Tabel 1.2 Provinsi dengan Jumlah Penduduk Terbanyak di Indonesia

\begin{tabular}{|c|l|c|}
\hline Peringkat & Provinsi & Jumlah Penduduk \\
\hline 1 & Jawa Barat & $48,037,600,000$ \\
\hline 2 & Jawa Tengah & $34,257,900,000$ \\
\hline 3 & Jawa Timur & $39,239,000,000$ \\
\hline
\end{tabular}

Sumber : BPS

Dari data tersebut dapat disimpulkan bahwa DKI Jakarta merupakan provinsi dengan jumlah PDRB terbesar, akan tetapi tidak masuk kategori dengan penduduk terbanyak. Sedangkan Jawa Barat merupakan provinsi dengan jumlah penduduk terbanyak namun hanya berada di peringkat ketiga dalam kategori provinsi dengan PDRB tertinggi, artinya penduduk Jawa Barat kurang produktif dalam menghasilkan PDRB.

Selain itu pertumbuhan PDRB Jawa Barat dalam lima tahun terakhir tidak tumbuh stabil (mengalami kenaikan dan penurunan) setiap tahunnya.

Tabel 1.3 Pertumbuhan PDRB Jawa Barat 2013-2017

\begin{tabular}{|c|c|c|}
\hline Tahun & $\begin{array}{c}\text { PDRB } \\
\text { (Juta Rupiah) }\end{array}$ & $\begin{array}{c}\text { Pertumbuhan } \\
(\%)\end{array}$ \\
\hline 2013 & $1,093,543,545.87$ & 6.3 \\
\hline 2014 & $1,149,216,057.05$ & 5.1 \\
\hline 2015 & $1,207,083,405.74$ & 5.0 \\
\hline 2016 & $1,275,546,477.51$ & 5.7 \\
\hline 2017 & $1,343,864,432.16$ & 5.4 \\
\hline
\end{tabular}

Sumber : BPS

Dengan kondisi tersebut perlu adanya perhatian dalam meningkatkan PDRB Jawa Barat, karena minimnya kontribusi penduduk dalam menghasilkan output pemerintah perlu menggali sumber-sumber dan potensi yang dimiliki Jawa Barat guna memacu kenaikan PDRB, sehingga Jawa Barat dapat berkontribusi lebih besar dibandingkan tahun sebelumnya dalam meningkatkan pertumbuhan ekonomi nasional. 
Mengacu pada penelitian Cok istri dan Ida Bagus (2014) yang berjudul Pengaruh PMDN dan PMA Terhadap PDRB di Provinsi Bali. Hasil penelitiannya menunjukkan bahwa PMA berpengaruh signifikan secara simultan terhadap Produk Domestik Regional Bruto dan PMDN berpengaruh positif dan signifikan terhadap Produk Domestik Regional Bruto. Yeni\&Suratno (2015) menyatakan bahwa faktor-faktor yang mempengaruhi pertumbuhan PDRB di Indonesia yaitu PAD, DAU, DAK dan DOK. Hasil penelitiannya menyatakan bahwa PAD, DAU, DAK dan DOK berpengaruh signifikan terhadap PDRB.

Dalam sebuah teori, Harrod-Domar menekankan bahwa pembentukan investasi sangat penting bagi pertumbuhan ekonomi yang berperan sebagai tambahan stok modal. Semakin tinggi tingkat investasi, maka perekonomian akan mampu memproduksi barang dan jasa dengan jumlah yang lebih besar, sehingga akan meningkatkan jumlah PDRB. Berdasarkan sumbernya salah satu investasi yang modal nya berasal dari dalam negeri yaitu Penanaman Modal Dalam Negeri (PMDN) yang dapat dilakukan oleh perseorangan WNI, badan usaha dalam negeri, dan pemerintah dalam negeri.

Selain investasi, pendapatan daerah juga berperan penting dalam menjadi modal atas pergerakan perekonomian daerah. Pendapatan Asli Daerah (PAD) merupakan sumber pendapatan terbesar yang ada di APBD yang berperan menanggung sebagian beban belanja daerah. Dana Alokasi Umum (DAU) adalah bagian dari dana perimbangan yang bersumber dari pendapatan dalam negeri yang diberikan dari pemerintah pusat ke pemerintah daerah dan dialokasikan dengan tujuan pemerataan kemampuan keuangan antar-daerah untuk mendanai kebutuhan daerah dalam rangka pelaksanaan desentralisasi (UU No. 33 tahun 2004).

Mengacu pada teori pengeluaran pemerintah, Wagner menyatakan bahwa dalam suatu perekonomian apabila pendapatan per kapita meningkat maka secara relatif pengeluaran pemerintah pun akan meningkat terutama disebabkan karena pemerintah harus mengatur hubungan yang timbul dalam masyarakat, hukum, pendidikan, rekreasi, kebudayaan dan sebagainya. Dalam teori ekonomi makro, pengeluaran pemerintah terdiri dari tiga pos utama yang dapat digolongkan sebagai berikut (Boediono,1999) :

1. Pengeluaran pemerintah untuk pembelian barang dan jasa.

2. Pengeluaran pemerintah untuk gaji pegawai. Perubahan gaji pegawai mempunyai pengaruh terhadap proses makro ekonomi, di mana perubahan gaji pegawai akan mempengaruhi tingkat permintaan secara tidak langsung.

3. Pengeluaran pemerintah untuk transfer payment. Transfer payment bukan pembelian barang atau jasa oleh pemerintah dipasar barang melainkan mencatat pembayaran atau pemberian langsung kepada warganya yang meliputi misalnya pembayaran subsidi atau bantuan langsung kepada berbagai golongan masyarakat, pembayaran pensiun, pembayaran bunga untuk pinjaman pemerintah kepada masyarakat. Secara ekonomis transfer payment mempunyai status dan pengaruh yang sama dengan pos gaji pegawai meskipun secara administrasi keduanya berbeda. (Boediono, 1999)

Sejalan dengan tiga pos utama pengeluaran pemerintah tersebut tentunya terdapat beberapa dampak, salah satunya bagi kenaikan PDRB. Dilihat dari pembelian barang dan jasa oleh pemerintah, dan diikuti oleh pengeluaran pemerintah untuk gaji pegawai, serta adanya subsidi atau bantuan langsung kepada berbagai golongan masyarakat, dan dana pensiun. pengeluaran pemerintah tersebut akan berimplikasi terhadap kenaikan tingkat konsumsi, lalu permintaan barang dan jasa meningkat, dan produsen akan menaikkan tingkat produksi barang dan jasa. maka terjadilah kenaikan PDRB yang dipengaruhi oleh Pendapatan Asli Daerah (PAD), dan Dana Alokasi Umum (DAU). Karena pendapatan daerah menjadi modal atas pergerakan perekonomian masing-masing daerah.

Berdasarkan penelitian sebelumnya dapat dilihat bahwa banyak sekali faktor yang mempengaruhi PDRB, serta dari pengamatan beberapa teori penulis ingin meneliti lebih lanjut beberapa faktor yang mempengaruhi PDRB Jawa Barat dan seberapa besar faktor tersebut berpengaruh terhadap PDRB Jawa Barat. Sehingga penelitian ini diberi judul dengan "Pengaruh PAD, DAU, dan PMDN terhadap PDRB Jawa Barat 2003-2017”

Berdasarkan latar belakang diatas, maka dapat diidentifikasikan masalah sebagai berikut : 
1. Bagaimana pengaruh PAD, DAU, dan PMDN terhadap PDRB Provinsi Jawa Barat 20032017 ?

2. Berapa besar pengaruh PAD, DAU, dan PMDN terhadap PDRB Provinsi Jawa Barat 2003-2017?

\section{B. Landasan Teori}

Pertumbuhan ekonomi merupakan upaya peningkatan kapasitas produksi untuk mencapai penambahan output, yang diukur menggunakan Produk Domestik Bruto (PDB) maupun Produk Domestik Regional Bruto (PDRB) dalam suatu wilayah (Ahmad\&Lastri,2008).

\section{Hubungan antara PAD terhadap PDRB}

PAD dengan PDRB memiliki hubungan positif, alasannya karena PAD merupakan sumber pendapatan daerah terbesar yang ada dalam APBN, dimana dana PAD digunakan untuk anggaran belanja daerah. Jika PAD meningkat maka anggaran belanja yang dimiliki oleh pemerintah daerah akan lebih tinggi. Semakin tinggi belanja pemerintah dalam pembelian barang dan jasa serta transfer payment maka akan berimplikasi pada kenaikan PDRB.

\section{Hubungan antara DAU terhadap PDRB}

Dana Alokasi Umum merupakan salah satu bagian dari Dana perimbangan, Berdasarkan pada Peraturan Pemerintah Nomor 55 tahun 2005, dana perimbangan tersebut dibentuk untuk mendukung pendanaan program otonomi. Dana Alokasi Umum bersifat Block Grant yang bearti penggunaannya diserahkan kepada daerah sesuai dengan prioritas dan kebutuhan daerah untuk peningkatan pelayanan kepada masyarakat dalam rangka pelaksanaan otonomi daerah.

Semakin tinggi DAU suatu provinsi dan kabupaten/kota, maka akan semakin tinggi belanja daerah di wilayah tersebut yang mengakibatkan perputaran produktivitas barang maupun jasa yang meningkatkan PDRB di wilayah tersebut. Maka dapat disimpulkan bahwa DAU berpengaruh positif terhadap PDRB.

\section{Hubungan antara PMDN terhadap PDRB}

Harold dan Dommar memberikan peran kunci kepada investasi terhadap peranannya dalam proses pertumbuhan ekonomi khususnya mengenai peran ganda yang dimiliki investasi. Pertama, investasi memiliki peran ganda dimana dapat menciptakan pendapatan, dan yang kedua,investasi memperbesar kapasitas produksi perekonomian dengan cara meningkatkan stok modal (Eko Prasetyo,2009).

\section{Hasil Penelitian dan Pembahasan \\ Uji Asumsi Klasik}

1. Uji Autokorelasi

Tabel 3.1 Uji Autokorelasi

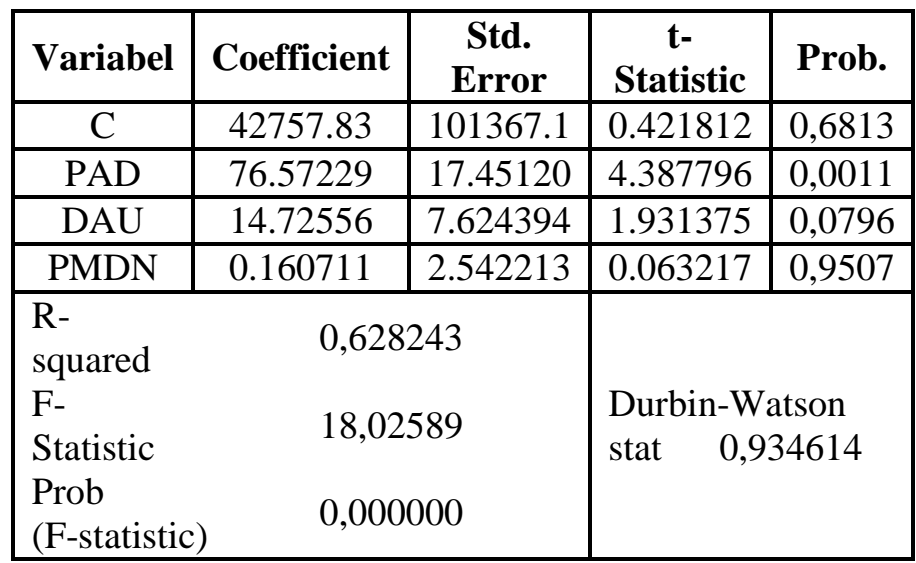

Sumber: Perhitungan Eviews 
Pada hasil estimasi regresi awal terdapat masalah autokorelasi. Masalah autokorelasi dapat dihilangkan menggunakan metode Newey-West HAC. Sehingga model regresi dapat digunakan untuk menjelaskan faktor-faktor yang mempengaruhi PDRB.

2. Uji Heterokedastisitas

Nilai Prob.Chi-Square(9) $=0.1475>\alpha=0,05$ maka H0 diterima, artinya tidak terdapat masalah heterokedastisitas dalam model regresi.

3. Uji Normalitas

Nilai Probability $=0.166824>\alpha=0.05$ maka H0 diterima, artinya residual regresi dalam penelitian ini berdistribusi normal.

4. Uji Multikolinearitas

Table 3.2 Uji Multikolinearitas

\begin{tabular}{|c|c|l|l|l|}
\hline $\mathrm{R}^{2}$ & $\geq l \leq$ & $\mathrm{r}^{2} 1,2,3$ & $\mathrm{r}^{2} 2,1,3$ & $\mathrm{r}^{2} 3,1,2$ \\
\hline 0.86383 & $>$ & 0.689271 & 0.01694 & 0.68712 \\
\hline
\end{tabular}

Sumber: Hasil diolah dengan menggunakan Eviews versi 9.0

Hasil output regresi menunjukkan bahwa $\mathrm{R}^{2} 1>\mathrm{r}^{2} 1,2,3, \mathrm{r}^{2} 2,1,3, \mathrm{r}^{2} 3,1,2$, maka di dalam model regresi tidak diketemukan adanya multikolinearitas.

\section{Uji Statistik}

1. Uji Parsial (Uji t)

Tabel 3.3 Uji Parsial (Uji-t)

\begin{tabular}{|l|l|c|c|l|}
\hline Variabel & Prob & $\geq / \leq$ & A & Kesimpulan \\
\hline PAD & 0.0008 & $<$ & 0.01 & Signifikan \\
\hline DAU & 0.0003 & $<$ & 0.01 & Signifikan \\
\hline PMDN & 0.9463 & $>$ & 0.01 & $\begin{array}{l}\text { Tidak } \\
\text { signifikan }\end{array}$ \\
\hline
\end{tabular}

Sumber: Hasil diolah dengan menggunakan Eviews versi 9.0

\section{Uji t terhadap Koefisien B1 dari PAD}

Berdasarkan hasil estimasi dapat diketahui PAD memiliki nilai koefisien positif dan nilai probabilitas t-hitung $0.0008<\alpha=0.01$, maka H0 ditolak dan H1 di diterima. Dengan diterimanya $\mathrm{H} 1$ artinya variabel PAD berpengaruh positif dan signfikan terhadap PDRB dengan tingkat signifikan $99 \%$.

\section{Uji t terhadap Koefisien B2 dari DAU}

Berdasarkan hasil estimasi dapat diketahui DAU memiliki nilai koefisien positif dan nilai probabilitas t-hitung $0.0003<\alpha=0.01$, maka H0 ditolak dan $\mathrm{H} 1$ di diterima. Dengan diterimanya H1 artinya variabel DAU berpengaruh positif dan signfikan terhadap PDRB pada tingkat signifikan $99 \%$.

\section{Uji t terhadap Koefisien B3 dari PMDN}

Berdasarkan hasil estimasi dapat diketahui PMDN memiliki nilai koefisien positif dan nilai probabilitas t-hitung $0.9463>\alpha=(0,01),(0,05)$ dan $(0,1)$ maka H0 diterima H1 ditolak. Dengan diterimanya $\mathrm{HO}$ artinya variabel PMDN berpengaruh positif tetapi tidak signfikan terhadap PDRB.

1. Uji Serempak (Uji F)

Uji F digunakan untuk menguji apakah secara statistik koefisien regresi dari variabel independen secara bersama-sama memberikan pengaruh terhadap variabel dependen.

Dengan derajat kebebasan $(3,11)$ dan $\alpha=0,01$ Nilai F-tabel=6,22. Dari hasil regresi diketahui bahwa nilai F-statistik adalah 23.27092 Dengan demikian F-statistik > nilai F-tabel, maka H0 ditolak dan H1 diterima, artinya secara bersama-sama variabel PAD, DAU, dan PMDN berpengaruh signifikan terhadap PDRB. 
2. Interpretasi Koefisien Determinasi

Dari hasil regresi diketahui bahwa nilai R-squared adalah 0.863883 , yang berarti variasi dari variabel PAD, DAU, dan PMDN dapat menjelaskan variasi variabel Produk Domestik Regional Bruto sebesar 86,3883\%, sedangkan sisanya (13,6117\%) PDRB dijelaskan oleh variabel-variabel lain yang tidak dimasukkan dalam model.

\section{Pengaruh PAD Terhadap PDRB}

Nilai Probabilitas Variabel PAD menunjukkan nilai signifikan dengan koefisien 76.57231 artinya PAD berpengaruh positif dan signifikan. Hasil ini menunjukkan bahwa setiap terjadi kenaikan pada PAD sebesar 1 Juta, maka PDRB akan mengalami peningkatan sebesar 76,59 Juta. Hal ini menandakan bahwa PAD berperan penting dalam meningkatkan PDRB Jawa Barat.

Hasil penelitian ini konsisten dengan hasil penelitian Yeni Nur'aeni dan Suratno (2015), Eko dan I Nyoman (2014), Trias dan Hastarini (2013) yang menyatakan bahwa PAD berpengaruh positif dan signifikan terhadap PDRB Jawa Barat.

Pengaruh PAD terhadap PDRB dapat dijelaskan melalui fakta bahwa PAD merupakan Pendapatan Daerah yang ada dalam APBD, dimana PAD di akumulasikan sebagai modal untuk belanja daerah. Disimpulkan dalam Teori Wagner bahwa semakin tinggi angka PAD maka semakin tinggi pula belanja pemerintah, di mulai dari pembelian barang dan jasa oleh pemerintah, dan diikuti oleh pengeluaran pemerintah untuk gaji pegawai, serta adanya subsidi atau bantuan langsung kepada berbagai golongan masyarakat, dan dana pensiun. pengeluaran pemerintah tersebut akan berimplikasi terhadap kenaikan tingkat konsumsi, lalu permintaan barang dan jasa meningkat, dan Produsen akan menaikkan tingkat Produksi barang dan jasa, maka terjadilah kenaikan PDRB. Pengaruh PAD yang signifikan terhadap PDRB ini menunjukkan bahwa kemampuan Pemerintah Jawa Barat dalam melaksanakan otonomi daerah terlihat efektif dan efisien

\section{Pengaruh DAU Terhadap PDRB}

Nilai Probabilitas variabel DAU menunjukkan nilai signifikan dengan koefisien 14.72557 artinya DAU berpengaruh positif dan signifikan. Hasil ini menunjukkan bahwa setiap terjadi kenaikan pada DAU sebesar 1 Juta, maka PDRB akan mengalami peningkatan sebesar 14,72 Juta. Hal ini menandakan bahwa DAU berperan penting dalam meningkatkan PDRB Jawa Barat. Hasil penelitian ini konsisten dengan hasil penelitian Yeni Nur'aeni dan Suratno (2015).

Pengaruh DAU terhadap PDRB dapat dijelaskan melalui DAU yang bersifat Block Grant yang berarti penggunaannya diserahkan kepada daerah sesuai dengan prioritas dan kebutuhan daerah untuk peningkatan pelayanan kepada masyarakat dalam rangka pelaksanaan otonomi daerah. Semakin tinggi dana DAU, semakin tinggi belanja pemerintah dalam meningkatkan pelayanan untuk masyarakat.

Dengan adanya peningkatan pelayanan seperti kesehatan, pendidikan serta pembangunan infrastruktur maka akan berdampak pada peningkatan kualitas Sumber Daya Manusia dan peningkatan lapangan kerja yang akan mengurangi pengangguran, meningkatkan pendapatan perkapita, menaikkan tingkat konsumsi kemudian berimplikasi pada kenaikan PDRB.

Kemudian peningkatan pelayanan masyarakat dalam pembangunan infrastruktur akan menciptakan permintaan barang dan jasa untuk barang publik mengacu pada Teori Mikro Pengeluaran Pemerintah, interaksi antara permintaan dan penawaran akan barang publik menentukan jumlah barang publik yang akan disediakan melalui anggaran belanja. Contohnya, pemerintah akan membuat jalan tol, maka yang akan dibutuhkan adalah tenaga kerja serta alat dan bahan pembuatan jalan tol yang akan dihasilkan oleh sektor industri. Produksi akan barang dan jasa yang diperlukan pemerintah akan meningkatkan PDRB.

\section{Pengaruh PMDN Terhadap PDRB}

Nilai Probabilitas variabel PMDN menunjukkan bahwa PMDN tidak berpengaruh secara signifikan terhadap PDRB Jawa Barat. Hasil penelitian ini konsisten dengan hasil penelitian Kurnia Martikasari (2016) yang menyatakan hal ini disebabkan karena PMDN bukan merupakan satu-satunya faktor yang berperan besar dalam peningkatan PDRB. Penggunaan 
PMDN untuk pembangunan sering kurang tepat sasaran, sehingga tidak dapat meningkatkan PDRB. Hal ini menunjukkan bahwa daerah belum memberikan iklim yang kondusif bagi investor dalam maupun luar negeri. Iklim yang belum kondusif tersebut ditandai dengan masih rendahnya pelayanan publik, kurangnya kepastian hukum serta berbagai peraturan daerah (Perda) yang kurang "pro-bisnis". Pelayanan publik yang masih rendah terutama terkait dengan ketidakpastian biaya, lamanya waktu perijinan usaha dan birokrasi, serta masih adanya berbagai pungutan baik pengutan resmi maupun pungutan liar. Alasan utama para investor masih khawatir untuk melakukan investasi yaitu faktor ketidakstabilan ekonomi makro, ketidakpastian kebijakan, korupsi, birokrasi dan perijinan, serta regulasi pasar tenaga kerja.

Investasi yang rendah akan membuat peranan nya untuk menghasilkan output menjadi minim karena modal yang terbatas, dan penggunaan PMDN yang kurang tepat sasaran biasanya terjadi karena PMDN digunakan untuk memperbaiki barang-barang bangunan, material, peralatan dan lainnya yang mengalami kerusakan, dan pembelian mesin baru, sehingga pemanfaatan modal tidak langsung kepada proses produksi yang menghasilkan output.

\section{Kesimpulan}

Berdasarkan hasil penelitian, maka dapat ditarik kesimpulan sebagai berikut:

1. Berdasarkan hasil uji secara serempak (uji-f), variabel PAD, DAU, dan PMDN secara bersama-sama berpengaruh signifikan terhadap PDRB Provinsi Jawa Barat 2003-2017. Berdasarkan hasil pengujian secara parsial (uji-t) PAD dan DAU berpengaruh positif dan signifikan terhadap PDRB. Sedangkan variabel PMDN berpengaruh positif tetapi tidak signifikan.

2. Berdasarkan hasil perhitungan koefisien determinasi (R2) diketahui bahwa besarnya pengaruh PAD, DAU, dan PMDN terhadap PDRB adalah sebesar adalah 0.863883, yang berarti variasi dari variabel PAD, DAU, dan PMDN dapat menjelaskan variasi variabel Produk Domestik Regional Bruto sebesar 86,3883\%, sedangkan sisanya $(13,6117 \%)$ PDRB dijelaskan oleh variabel-variabel lain yang tidak dimasukkan dalam model. 3.

\section{Daftar Pustaka}

[1] Badan Pusat Statistik (BPS) Dalam Angka 2003-2016

[2] Boediono. 1999. Teori Pertumbuhan Ekonomi. BPFE Yogyakarta.Yogyakarta.

[3] Ekonometrika dan Stastistika dengan Evews Edisi 3. Yogyakarta : UPP STIM YKPN.

[4] Halim,Abdul. 2004. Akuntansi Keuangan Daerah. Salemba Empat. Jakarta.

[5] Karlita, Batari Saraswati, and Edy Yusuf AG. "Pengaruh Investasi, Tenaga Kerja, dan Ekspor terhadap PDRB Sektor Industri di Kota Semarang Tahun 1993-2010" Diponegoro Journal of Economics, vol. 2, no. 4, 2013, pp. 32-39, Neliti.

[6] Maisaroh, Mamai dan Havid Risyanto. "Pengaruh Investasi, Pengeluaran Pemerintah dan Tenaga Kerja terhadap PDRB Provinsi Banten" Ekbis, 2017.

[7] Mamonto, Winda Srilianti (2013). Pendapatan Asli Daerah (PAD) dan Tenaga Keerja Pengaruhnya Terhadap PDRB Kota Kotamobagu Periode 2002-2011. Universitas Sam Ratulangi Manado.Manado

[8] Nur'aeni,Yeni dan Suratno (2015). Pengaruh PAD,DAU,DAK dan DOK Terhadap Produk Regional Domestik Bruto. Universitas Pancasila. Jakarta Selatan

[9] Prasetya,Ferry.2012. Ekonomi Publik(Modul).Universitas Brawijaya.Malang.

[10] Sodik, Jamzani, and Didi Nuryadin. "Investasi dan Pertumbuhan Ekonomi Regional (Studi Kasus pada 26 Propinsi di Indonesia, PRA dan Pasca Otonomi." Economic Journal of Emerging Markets, vol. 10, no. 2, 2005.

[11] Sugiyono, 2010. Metode Penelitian Kuantitatif Kualitatif dan R\&D. Bandung: Alfabeta.

[12] Sulianto, 2011. Ekonometrika Terapan:Teori dan Aplikasi Dengan SPSS,CV.ANDI OFFEST.Yogyakarta

[13] Winarno, Wing Wahyu. 2011.Analisis Ekonometrika dan Stastistika dengan Evews Edisi 3. Yogyakarta : UPP STIM YKPN. 